\title{
Professional Ethics in Providing Credits for MSMEs
}

\author{
Yanuar Ramadhan*, Charlin Sitompul, Dian Oktavia \\ Universitas Esa Unggul \\ Jakarta, Indonesia \\ *yanuar.ramadhan@esaunggul.ac.id
}

\begin{abstract}
Professional ethics is a branch of ethics that critically and systematically reflects the moral problems inherent in a profession. Sometimes, Business Ethics also called management ethics is the application of moral standards in business activities. Business is an individual business activity that is organized to produce and sell goods and services in order to get benefit in meeting the needs of the community. Business means also the total number of businesses which include agriculture, production, construction, distribution, transportation, communication, service businesses and government engaged in making and commercializing goods and services to consumers. Business ethics must be seen as an element in the business venture itself. Business without ethics in the long term will not succeed. Nowadays, there have been many cases, especially in the Micro, Small and Medium Enterprises (MSMEs) sector, which in essence do not apply business ethics so causing problems which result in losses both in terms of banking and debtors. MSMEs is one of the business sectors in Indonesia which has an important role. Especially in small cities, this sector is very helpful in developing the potential area. It also can open employment that aim to reduce unemployment. But most of these businesses still face obstacles, namely capital problems. In order to overcome this, the government has endeavored to make a policy that is the existence of Micro, Small and Medium Enterprises (MSMEs) Credit with the aim of helping the community, especially business owners to increase their business capital. In observations used descriptive qualitative observational methods and supported by data obtained from direct observation or surveillance, archive documentation, interviews with bank employees and customers. Despite the obstacles, bank officer tries to carry out the procedure of lending in accordance with the provisions and provide the best service for customers.
\end{abstract}

Keywords—ethics, MSMEs, professional ethics

\section{INTRODUCTION}

Micro, Small and Medium Enterprises (MSMEs) are an important part of the economy of a nation and region, including Indonesia. The development of MSMEs currently plays an important role for the backbone of the Indonesian economy in line with government policies in terms of helping MSMEs to become stronger and more competitive. This certainly cannot be separated from the ability of MSMEs in increasing their financial capital [1].

Micro, Small and Medium Enterprises (MSMEs) have an important and strategic role in national economic development.
In addition to playing a role in economic growth and employment, MSMEs also play a role in distributing development results. MSMEs have also been proven not to be affected by the crisis. When the crisis hit in the period 1997 1998, only MSMEs were able to remain strong [2]

Chairman of the Indonesian Micro and Small Business Association (Akumindo) Ikhsan Ingratubun explained, with the estimated growth, he believed the total contribution of MSMEs to the national gross domestic product (GDP) in 2019 could reach $65 \%$ or around Rp2,394.5 trillion. Meanwhile, the realization of the contribution of MSMEs to the national GDP in 2018 reached around $60.34 \%$. Seeing the big role of Micro, Small and Medium Enterprises (MSMEs) actors, it is necessary to give a bigger portion, so that many parties urge both the government and legislature, which finally produced Law number 20 of 2008, concerning Micro, Small and Medium Enterprises (MSMEs), as a legal protection in order to move more freely [3].

Minister of Cooperatives and SMEs, Teten Masduki revealed, the number of Indonesian entrepreneurs, 99 percent are micro, small, and medium enterprises (MSMEs). Meanwhile, 98 percent, is micro scale. According to him, 99 percent of MSME businesses have a contribution to GDP of 60.34 percent. Meanwhile, the employment of 97 percent. However, the majority of bank lending or more than $81 \%$ of the total lending is given to large business or corporate actors [4,5].

Micro, Small, and Medium Enterprises (MSMEs) The characteristics of MSMEs are the factual characteristics or conditions inherent in business activities and the behavior of the entrepreneurs concerned in conducting their business. This characteristic is the distinguishing characteristic of business actors according to the scale of business. According to the World Bank, MSMEs can be grouped into three types, namely: Micro Business (10 employees); Small Business (number of employees 30 people); and Medium Business (number of employees up to 300 people).

In a business perspective, MSMEs are classified into four groups, namely: 1) MSMEs in the informal sector, for example street vendors, 2) Micro MSMEs are MSMEs with the ability of the craftsmen but lack the entrepreneurial spirit to develop their business, 3) Dynamic Small Business is a group of MSMEs that are capable of entrepreneurship by establishing 
cooperation (accepting sub-contract work) and exports, and 4) Fast Moving Enterprise is an MSMEs that has competent entrepreneurship and is ready to transform into a big business.

Financial capital plays a very important role for an entrepreneur to start and develop a business that is already operational. Capital is often a booster for MSMEs to develop. It is not uncommon for MSMEs to discourage them from developing their businesses to become bigger because they do not get enough capital.

Micro, small and medium enterprises are one of the driving forces of the Indonesian economy. Since the monetary crisis in 1997-1998, almost $80 \%$ of businesses categorized as big experienced bankruptcy and instead MSMEs can survive the crisis with all the limitations and capabilities they have, among others [2].

First, the role of the management institution for Micro, Small and Medium Enterprises (MSMEs) has become increasingly important and has benefited the community for the past six years. There are many achievements that have been successfully achieved so far, especially its contribution in the development and empowerment of cooperatives and micro and small and medium enterprises. Second, People's Business Credit (KUR), whose main target is cooperative entrepreneurs and micro, small and medium enterprises that are worthy of business, but do not yet have adequate financial capital. The People's Business Credit (KUR) program also forms part of the process of developing and empowering cooperatives and micro and small and medium enterprises. Third, From the results of the program released by the government, the development of Micro, Small and Medium Enterprises (MSMEs) has increased significantly every year [5]

If the capital owned by MSMEs is insufficient, then one of the solutions taken by MSMEs is to apply for credit to the bank. However, one of the conditions that is often an obstacle for MSMEs to get credit from banks is collateral problems. Starting from having no collateral at all, the collateral owned is inadequate and the collateral owned does not have sufficient legality (for example: land without certificates).

In addition, one of the things that makes banks cautious about giving credit is the risk that can arise in lending in the form of failure to meet obligations to the Bank in accordance with the agreement that can cause bad credit.

Some examples of cases that occurred in connection with lending: a marketing of a bank was arrested by the police for falsification and embezzlement of disbursed loans (Kredit Tanpa Agunan/KTA) in a private bank in South Jakarta. The suspect made a profit of around Rp 100 million more than the proceeds of the crime; Provision of credit with fictitious documents and guarantees to one of the banks involving the bank account officer in Jakarta; the existence of a bill to someone who is concerned has never made a credit card, but suddenly a bill of tens of millions; fictitious credit cases involving banks in West Java and Banten to one of the companies that began to be revealed where the bank as the lender did not have collateral or collateral from the debtor. Because, as the debtor actually pledges the motherland and buildings to other banks; The Republic of Indonesia National Police Criminal Investigation Agency arrested an official of one of the banks related to a credit case to a company, in which one of the bank persons allegedly played a role in processing credit applications to the company. The person allegedly received compensation from the debtor.

The Financial Services Authority (Otoritas Jasa Keuangan/OJK) said there are at least four modes that are most widely committed by financial criminals in carrying out their actions, including fictitious credit, takeover of bank cash for personal gain, placement of funds that are not appropriate and finally records of expenses that are not in accordance with actual banking operations [6].

\section{LITERATURE REVIEW}

Looking at the activities of the guarantee institution which focuses on the temporary takeover of the risk of bad credit from MSMEs as guaranteed. In this case if MSMEs as debtors cannot repay their obligations in accordance with the agreed time period, the guarantor institution will complete the fulfillment of these obligations to the bank as the creditor. Settlement of the remaining bad credit remains the obligation of the debtor as guaranteed either by installments or the sale of collateral [7].

If one of the party states that it is not feasible, a guarantee cannot be given to MSMEs. It is also important to be understood by MSMEs that business feasibility is not only an evaluation of the financial side but also of personal characteristics and businesses that deserve to be guaranteed [8].

As is usual in banks in granting loans is required to provide collateral whose value is at least equivalent to the amount of credit submitted. This is where the role of the Guarantee Institution can be a solution for MSMEs as a substitute for collateral if MSMEs collateral is not sufficient [9].

Can be known about the procedure for granting MSMEs Credit, namely: submitting a loan application, investigating and analyzing credit, making credit decisions and realizing credit. Broadly speaking, the procedure for giving MSMEs credit has been running in accordance with existing provisions. However, in carrying out their duties, officers still encounter obstacles, namely the problem of completeness of credit application documents. Even though they encountered obstacles, the officers tried to carry out the procedure of giving credit according to the provisions and provided the best service for the customers [10].

The growth of national banking loans, in general, in the last 5 years was $9.24 \%$, and the growth of Micro, Small and Medium Enterprises (MSMEs) loans, on average in the last 5 years of $8.76 \%$ experienced a downward growth from year to year. There is no research or analysis that can be used as a reference, but from the results of discussions with several economic actors that credit growth is significant enough to 
affect economic growth in general. As we can feel together in the last 4 to 5 years, there has been an economic slowdown and even Indonesia's economic growth has not reached the target set. While the ratio of credit to Micro, Small and Medium Enterprises (SMEs), is still below $20 \%$ and even tends to decrease [11].

Credit appraisal by banks can be done in various ways to gain confidence about their customers, such as through true and serious appraisal procedures. In conducting an assessment, the criteria and aspects of the assessment remain the same. Likewise, the standards set have become standard assessments for each bank. Usually the assessment criteria are general and must be carried out by the bank to get customers who are truly eligible to be given, carried out with an analysis of $5 \mathrm{C}$ and $7 \mathrm{P}$ [12-15].

First $\mathrm{C}$ is Character, is the personality or characteristic of a person. The personality or characteristic of the people to be given credit really needs to be trustworthy. To bring the personality or characteristic of the prospective debtor can be seen from the background of work or personal, such as the way of life or lifestyle that it contains, family circumstances, hobbies, and social life. From the nature and character of this can be used as a measure of the "willingness" of customers to pay. Second C is, Capacity, is an analysis to determine the ability of customers in paying credit. This assessment shows the ability of customers to manage the business. This ability is related to the educational background and experience so far in managing his business, so that his "ability" in returning credit is shown. Capacity is often also referred to as capability. Third $\mathrm{C}$ is Capital, to see whether users of capital are effective or not, can be seen from the financial statements (balance sheet and income statement) presented by taking measurements such as in terms of liquidity and solvency, profitability and other measures. The capital analysis must also analyze which sources of capital are currently available, including the percentage of capital used to finance the project to be carried out, how much is its own capital and how much is the loan capital. Fourth $\mathrm{C}$ is Conditions, in assessing credit should also be assessed economic conditions, social, and politics that exist now and predictions for the future. An assessment of the conditions or prospects of the business sector funded by the University of North Sumatra should really have good prospects, so the possibility of the credit problem is relatively small. Fifth $\mathrm{C}$ is Collateral, is a guarantee given by prospective customers that is both physical and non-physical characteristic. Guarantees should exceed the amount of credit given. Guarantees must also be examined for their validity and perfection, so that if a problem occurs, the guarantee deposited can be used as quickly as possible [13]

In addition to the $5 \mathrm{C}$ principle, another principle used by financial institutions in providing credit is the $7 \mathrm{P}$ principle. In this principle there are seven criteria that must be met, namely: 1) Personality, i.e. the personality of prospective borrowers who apply for credit 2) Party, where prospective borrowers are included in several groups related to their financial condition, 3) Purpose, namely what is the purpose of prospective borrowers in applying for credit to financial institutions, 4) Prospect, which is how the prospect of a business run by prospective borrowers, 5) Payment, the fifth criterion is also aimed at measuring how the repayment ability of prospective borrowers, 6) Profitability, where the bank sees how the ability of prospective borrowers in generating profits or profits, 7) Protection, this protection criterion also refers to guarantees that can be given by prospective borrowers [14].

\section{METHODS}

Research is usually carried out by educational institutions especially higher education. The aim is to improve science and further understand natural and social phenomena that do not all have definite and correct answers. Although research is felt to be very important, but not all educators or industries are involved and interested in making research, this is due to various reasons both about lack of time, lack of facilities and unavailability of supporting funds.

Nevertheless, research remains an important activity carried out. already owned, as well as being able to show gaps and differences that exist in science; second, research deepens the knowledge that is already possessed, while at the same time being able to show gaps and differences that exist in science; secondly, research helps improve performance, being able to bring forth new ideas or thoughts, and be able to evaluate work performance that has been carried out so far, also for educators will share new research results that can be used and applied by other researchers in place, context and a different atmosphere; third, the results of a study can be input for public policy makers to improve the state of society both economic, social, cultural education, religion and other public services.

This research method begins by paying attention and analyzing the focus on the study case and paying attention to the subjective aspects of object behavior. Next, researchers explore information by meaning or give meaning to the study case. In qualitative research, the more in-depth, thorough, and excavated the data obtained, it can also be interpreted that the better the quality of the research. Qualitative research methods have fewer objects compared to quantitative research, because they prioritize the depth of data, and not the quantity of data. This type of research is conducted in the form of quantitative descriptive, with the aim of providing an overall conception of the development and growth of credit or financing distribution to Micro, Small and Medium Enterprises.

\section{RESULTS AND DISCUSSION}

\section{A. Results}

Micro, Small and Medium Enterprises (MSMEs) is one of the business sectors in Indonesia that has an important role [16]. Especially in small cities, this business is very helpful in developing the potential of an area. It also can open jobs that aim to reduce unemployment. But most of these businesses still face obstacles, namely financial capital problems [17]. In order to overcome this, the government has endeavored to make a 
policy that is the existence of Micro, Small and Medium Enterprises (MSMEs) Credit with the aim of helping the community especially business owners to increase their business capital [18]. The procedure for granting Micro, Small and Medium Enterprises (MSMEs) has been understood by banking employees. However, in its implementation, cases of violations are often found and appear in the mass media. Not a few cases that are not exposed by the mass media. In writing this research uses descriptive qualitative observational methods and supported by data obtained from direct observation or surveillance, archive documentation, interviews with employees and customers [19].

For credit guarantees provided by guarantee institutions, adjusted to the needs of MSMEs as Guaranteed and the amount of credit provided by banks as Recipients of Collateral. The amount of the loan guarantee value varies greatly from $60 \%$ to $80 \%$ of the value of the credit granted [20].

\section{B. Discussion}

In principle, the granting of credit guarantees always involves 3 parties, namely the guarantor institution as the guarantor, the bank as the recipient of the guarantee, and the MSMEs as guaranteed. Credit guarantees to MSMEs can only be granted if banks and guarantee institutions think that MSMEs businesses are feasible to be financed. Guarantee Institution is a legal entity or business entity in the field of nonbank finance with the main business activity of conducting guarantees as stipulated in Law Number 1 of 2016 concerning Guarantees. However, all these procedures will be in vain if professional ethics are not applied, both by bank employees, debtors, and from guarantee institutions.

Based on that, one of the solutions that can address the main problems of MSMEs is the provision of credit guarantees so that the collateral requirements and the risk of bad loans can be suppressed so that the intermediation function will run more safely [21]. All that while still paying attention and carrying out professional ethics as well.

\section{CONCLUSION}

Professional ethics for companies has a very important role, namely to form a company that is strong and has high competitiveness and has the ability to create high valuecreation, which requires a solid foundation to achieve it all. Every company, both large industrial companies and Micro, Small and Medium Enterprises (MSMEs) really needs the application of professional ethics in each of its activities. In order to create justice in the business that is run, and no party feels disadvantaged or get less profit compared to other parties.

Building professional ethical values starts with ourselves as managers and people who know this, look for weaknesses of the company that often occur, and make programs that must be run by the company in order to implement professional ethics really feels there. Don't underestimate a professional ethic because it is very important for the progress of the company itself. Without an ethic in business, the company may not last long because it will damage the good name of the company itself. Therefore, it is mandatory for all companies to apply a professional ethic or business ethics in their company.

In terms of credit quality, where in general credit is still very good, it is below $5 \%$ of the policy of the maximum limit of the soundness of banking, where the movement of credit quality is quite consistent, but for Micro, Small, and Medium Enterprises (MSMEs) loans are above average credit quality. This shows that MSMEs loans have a higher risk than large business or corporate loans. For credit guarantees provided by guarantee institutions, adjusted to the needs of MSMEs as Guaranteed and the amount of credit provided by banks as Recipients of Collateral. The amount of the loan guarantee value varies greatly from $60 \%$ to $80 \%$ of the value of the credit granted. In principle, the granting of credit guarantees always involves 3 parties, namely the guarantor institution as the guarantor, the Bank as the recipient of the guarantee and the MSMEs as guaranteed. Credit guarantees to MSMEs can only be granted if banks and guarantee institutions think that MSMEs businesses are feasible to be financed.

\section{REFERENCES}

[1] I.Y. Niode, "Perkembangan Dan Strategi Memberdayakan Usaha Mikro Kecil Dan Menengah (UMKM),” Jurnal FORMAS: Media Informasi \& Komunikasi Ilmiah Mahasiswa-Masyarakat, 2008.

[2] Merdeka, "Menteri Teten: UMKM Indonesia 98 Persennya Skala Mikro," [Online]. $\quad$ Retrieved from https://www.merdeka.com/uang/menteri-teten-umkm-indonesia-98persennya-skala-mikro.html

[3] M, Amelia R, "Begini Modus Oknum Marketing Bank Menilap Dana KTA Fiktif," [Online]. Retrieved from https://news.detik.com/berita/d3200872/begini-modus-oknum-marketing-bank-menilap-dana-kta-fiktif

[4] D. Syarizka, "Kontribusi UMKM terhadap PDB 2019 Diproyeksi Tumbuh 5\%," [Online]. Retrieved from https://ekonomi.bisnis.com/read/20190109/12/876943/kontribusi-umkmterhadap-pdb-2019-diproyeksi-tumbuh-5

[5] R.W. Griffin and R.J. Ebert, Bisnis Edisi Kedelapan. Jakarta: Erlangga, 2006.

[6] Otoritas Jasa Keuangan. Statistika Perbankan Indonesia September 2018. Otoritas Jasa Keuangan, 2019.

[7] Peraturan Bank Indonesia Nomor 7/2/PBI/2005. Indonesia, GB, 2015.

[8] Peraturan Bank Indonesia 1712 PBI 2015.

[9] Peraturan Kepala BPKP Nomor: PER1274/K/JF/2010 tentang Pendidikan, Pelatihan, dan Sertifikasi Auditor Aparat Pengawasan Intern Pemerintah.

[10] Peraturan Bank Indonesia Nomor 14/22/PBI/2012 Tentang Pemberian Kredit UMKM. Indonesia, G. B., 2005.

[11] Bank Indonesia \& LPPI, "Profil Bisnis Usaha Mikro, Kecil, dan Menengah (UMKM)," [Online]. Retrieved from https://www.bi.go.id/id/umkm/penelitian/nasional/kajian/Documents/Pro fil\%20Bisnis\%20UMKM.pdf.

[12] S. Agoes and I.C. Ardana, Etika Bisnis dan Profesi. Jakarta: Salemba Empat, 2009.

[13] L. Hartman, J. DesJardins, and C. MacDonald, Business Ethics: Decision Making for Personal Integrity \& Social Responsibility, 4th Ed. McGraw-Hill Education, 2017.

[14] Openstax College. Business Ethics, 2018. 
[15] W.H. Shaw, Business Ethics: A Textbook with Cases 9th Edition. Cengage Learning, 2016.

[16] S. Agoes, Auditing. Petunjuk Praktis Pemeriksaan Akuntan oleh Akuntan Publik. Jilid 1. Jakarta: Salemba Empat, 2011.

[17] A. Budiono, "Faktor-Faktor Yang Mempengaruhi Pertumbuhan Kredit Bank Umum Swasta Nasional (BUSN) di Indonesia," 2011.

[18] B. Primaraharjo and J. Handoko, "Pengaruh Kode Etik Profesi Akuntan Publik Terhadap Kualitas Audit Auditor Independen di Surabaya," Jurnal Akuntansi Kontemporer, no.1, pp. 27-51, 2011.
[19] M.K. Shaub, D.W. Finn and P. Munter, "Recent Economic Approaches and Financial Corporate Policy. 1993.

[20] F.M. Sholihah, "Pengaruh Orientasi Etika, Kompetensi dan Independensi Auditor Terhadap Kualitas Audit (Studi Empiris pada Auditor di Kantor Akuntan Publik Surakarta)," 2010.

[21] J.E. Ketz, Accounting Ethics, Critical Perspectives on Business and Management. Routledge, 2006. 